\title{
Pengaruh Komitmen dan Kompensasi terhadap Kinerja Dosen pada Perguruan Tinggi Swasta (PTS)
}

\author{
Rully Armanto \\ Universitas Tamansiswa \\ Email: armant.rully@gmail.com \\ Muji Gunarto*) \\ Universitas Bina Darma \\ Email: mgunarto@binadarma.ac.id
}

\begin{abstract}
This study aims to determine the effect of commitment and compensation on lecturer performance in private universities (PTS). The performance of lecturers in Indonesia, especially in PTS, is still considered unsatisfactory when compared to lecturers in state universities (PTN). The main factor that is suspected to be the cause is the commitment of the foundation as the owner and leader of the higher education institution as the manager and the compensation which is still low. The research sample was the permanent lecturers of the foundation at PTS in Palembang City, amounting to 44 respondents. The sampling technique used is cluster random sampling at Universities, Colleges, Academies and Polytechnics. The statistical analysis technique used multiple regression analysis with the help of SPSS software. The results showed that commitment and compensation had a significant effect on the performance of lecturers at private universities in Palembang City. The most dominant factor on the performance of PTS lecturers in Palembang City is compensation, meaning that by increasing the compensation for lecturers, their performance will increase. The results of this study really provide input for the improvement of private universities in Palembang City because when viewed from the permanent income of private universities in Palembang City, it is still below the average decent income of a lecturer.
\end{abstract}

Keywords: Commitment, Compensation, Lecturer Performance.

\begin{abstract}
Abstrak
Penelitian ini bertujuan untuk mengetahui pengaruh komitmen dan kompensasi terhadap kinerja dosen pada Perguruan Tinggi Swasta (PTS). Kinerja dosen di Indonesia khususnya di PTS masih dirasa belum memuaskan jika dibandingkan dengan dosen di Perguruan Tinggi negeri (PTN). Faktor utama yang diduga menjadi penyebabnya adalah komitmen yayasan sebagai pemilik dan pimpinan perguruan tinggi sebagai pengelola serta kompensasi yang dirasa masih rendah. Sampel penelitian adalah dosen tetap yayasan pada PTS di Kota Palembang yang berjumlah 44 orang responden. Teknik sampling yang digunakan adalah cluster random sampling pada Universitas, Sekolah Tinggi, Akademi dan Politeknik. Teknik analisis statistik digunakan analisis regresi berganda dengan bantuan software SPSS. Hasil penelitian menunjukkan bahwa komitmen dan kompensasi berpengaruh signifikan terhadap kinerja dosen pada PTS di Kota Palembang. Faktor yang paling dominan terhadap kinerja dosen PTS di Kota Palembang adalah kompensasi, artinya bahwa dengan meningkatnya kompensasi bagi dosen, maka kinerjanya akan meningkat. Hasil penelitian ini sangat memberikan masukan bagi perbaikann PTS di Kota Palembang karena jika dilihat dari pendapatan dosn tetap pada PTS di Kota Palembang masih dibawah rata-rata pendapatan layak seorang dosen.
\end{abstract}

Kata Kunci: Komitmen, Kompensasi, Kinerja dosen. 


\section{Pendahuluan}

Pendidikan merupakan bagian dalam pembangunan SDM yang diarahkan untuk mengembangkan SDM yang berkualitas. Upaya mencerdaskan kehidupan bangsa telah menjadi bagian dari strategi pembangunan nasional yang sangat penting dan dilandasi serta dijamin dengan perundang-undangan. Hasil observasi awal peneliti pada beberapa universitas swasta di Provinsi Sumsel diperoleh informasi bahwa kinerja dosen yang ada cenderung belum maksimal dalam melaksanakan tugas-tugas sebagai dosen dalam melaksanakan tri darma perguruan tinggi sesuai dengan standar akreditasi. Kenyataannya, hampir sebagian dari dosen tetap yang mengabdi pada universitas swasta di Provinsi Sumsel belum mampu untuk melaksanakan tri darma perguruan tinggi dengan baik.

Terdapat banyak faktor yang menyebabkan dosen tetap belum melaksanakan kinerja dengan baik, salah satunya adalah diduga karena kurangnya komitmen dari pihak yayasan sebagai pemilik dan komitmen pimpinan sebagai pengelola perguruaan tinggi. Faktor lain yang dianggap berpengaruh terhadap kinerja dosen adalah kurangnya kompensasi bagi dosen tetap, sehingga diprediksi berpengaruh pada motivasi kerja dan kinerja dosen tetap pada PTS tersebut.

Kinerja dosen berperan sangat penting dalam rangka mendorong keberhasilan penyelenggaraan suatu perguruan tinggi. Dalam konteks penyelenggaraan perguruan tinggi, Rummler dan Brache dalam Sudarmanto (2009) mengemukakan bahwa terdapat tiga jenis kinerja yang harus diperhatikan yaitu :

1. Kinerja organisasi; merupakan pencapaian hasil (outcome) pada level organisasi ini terkait dengan tujuan organisasi, rancangan organisasi, dan manajemen organisasi.

2. Kinerja proses; merupakan kinerja pada proses tahapan dalam menghasilkan produk atau pelayanan. Kinerja pada level proses ini dipengaruhi oleh tujuan proses, rancangan proses, dan manajemen proses.

3. Kinerja individu/pekerjaan; merupakan pencapaian atau efektivitas pada tingkat pegawai atau pekerjaan. Kinerja pada level ini dipengaruhi oleh tujuan pekerjaan, rancangan pekerjaan, dan manajemen pekerjaan serta karakteristik individu.

Bernardin (2003) menyatakan bahwa kinerja merupakan catatan hasil yang diproduksi atas fungsi pekerjaan tertentu atau aktivitas-aktivitas selama periode waktu tertentu. Berdasarkan beberapa defenisi di atas dapat dikatakan bahwa betapa pentingnya faktor kinerja dalam menunjang keberhasilan organisasi, proses dan SDM. Kinerja dilihat pada level organisasi, proses, dan individu.

Kinerja suatu perguruan tinggi akan tercapai dengan baik apabila unsur organisasi, proses dan individu berjalan dengan baik atau dengan kata lain kinerja akan dapat tercapai baik apabila di antaranya unsur organisasi berjalan dengan baik, misalnya bentuk organisasi yang tepat, aturan organisasi dan budaya organisasi yang sesuai. Secara keseluruhan, fenomena yang terjadi adalah sudah banyak melakukan pengajaran, namun kurang untuk melakukan penelitian dan pengabdian pada masyarakat. Hal ini menunjukkan kinerja dosen tetap belum memenuhi standar yang telah ditetapkan yaitu melaksanakan tri darma perguruan tinggi sesuai dengan kualifikasi akademiknya. 
Berdasarkan latar belakang permasalahan di atas, maka penulis tertarik untuk melakukan penelitian lebih lanjut tentang pengaruh komitmen dan kompensasi terhadap kinerja dosen PTS di Kota Palembang.

\section{Landasan Teori dan Pengembangan Hipotesis}

\subsection{Komitmen}

Menurut Greenberg (2013), arti komitmen adalah kesediaan seorang karyawan untuk memihak pada suatu organisasi tertentu dan tujuan-tujuannya serta berniat untuk memelihara keanggotaan dalam organisasi tersebut. Komitmen organisasi merupakan sikap yang menunjukkan sampai sejauh mana seseorang mengenal dan mau terikat dengan organisasinya. Jika seorang anggota memiliki komitmen yang tinggi, maka ia akan melihat dirinya sebagai anggota organisasi yang sejati. Menurut Kuntjoro (2015) komitmen organisasi adalah rasa identifikasi, keterlibatan, dan loyalitas yang dinyatakan oleh seseorang terhadap organisasinya. Komitment berasal dari kata latin "commiter" yang berarti menggabungkan, menyatukan, mempercayai dan mengerjakannya. Gibson dalam organisasi prilaku "Komitmen merupakan suatu rasa identifikasi, kesetiaan, dan keterlihatan yang diekspresikan oleh pegawai terhadap organisasi atau unit dari organisasi". Sedangkan organisasi menurut Wexley dan Yulk adalah "suatu pola hubungan antar manusia yang ikut serta dalam aktivitas dimana satu sama lainnya tergantung untuk suatu tujuan tertentu".

Luthans (2011) komitmen organisasi merefleksikan sikap loyalitas karyawan terhadap organisasinya. Karyawan dengan komitmen organisasi yang tinggi diindikasikan memiliki kebutuhan dan harapan yang tinggi terhadap organisasi tempatnya bekerja, serta lebih termotivasi saat harapannya terpenuhi. Sedangkan menurut Allen dan Meyer (1993) komitmen organisasi merupakan derajad seberapa jauh pekerja mengidentifikasi dirinya dengan organisasi dan keterlibatannya dengan organisasi. Dengan kata lain beberapa defenisi diatas menyatakan bahwa komitmen organisasi merefleksikan sikap seseorang dan bagaimana tingkat identifikasi dan keterlibatan seseorang dalam pekerjaannya dan ketidaksediaannya untuk meninggalkan pekerjaan tersebut.

Berdasarkan definisi di atas, dapat dikatakan bahwa dosen yang tidak memiliki komitmen organisasi dapat mengurangi efektivitas suatu universitas. Dosen tetap yang memiliki komitmen organisasi cenderung tidak berhenti dan menerima pekerjaan lain. Selain itu dosen tetap yang memiliki komitmen organisasi dan sangat terampil hanya memerlukan pengawasan yang lebih sedikit.

Salah satu faktor penting dalam perkembangan komitmen organisasi adalah penghargaan intrinsik. Perguruan tinggi sebagai organisasi diharapkan mampu memenuhi kebutuhan dosen tetap dengan menyediakan kesempatan pencapaian prestasi, dan mengakui pencapaian yang muncul akan memiliki perubahan yang signifikan dalam komitmen dosen tetapnya. Selain itu komitmen organisasi dosen tetap yang tinggi akan mendukung kinerja dosen tetap pada suatu universitas tersebut. Diharapkan melalui pemenuhan kebutuhan dan harapan para dosen tetap melalui organisasi tempatnya bekerja, akan dapat meningkatkan kinerja dosen tetap pada universitas tersebut. 


\subsection{Kompensasi}

Menurut Hasibuan (2017) kompensasi adalah semua pendapatan yang berbentuk uang, barang langsung atau tidak langsung yang diterima pegawai sebagai imbalan atas jasa yang diberikan kepada perusahaan. Kompensasi berbentuk uang, artinya kompensasi dibayar dengan sejumlah uang kartal kepada pegawai bersangkutan. Kompensasi berbentuk barang, artinya kompensasi dibayar dengan barang.

Kompensasi dibedakan menjadi dua yaitu kompensasi langsung (direct compensation) berupa gaji, upah, dan upah insentif; kompensasi tidak langsung (indirect compensation atauemployee welfare atau kesejahteraan pegawai). Gaji adalah balas jasa yang dibayar secara periodik kepada pegawai tetap serta mempunyai jaminan yang pasti. Maksudnya, gaji akan tetap dibayarkan walaupun pekerja tersebut tidak masuk kerja. Upah adalah balas jasa yang dibayarkan kepada pekerja harian dengan berpedoman atas perjanjian yang disepakati membayarnya. Upah insentif, adalah tambahan balas jasa yang diberikan kepada pegawai tertentu yang prestasinya di atas prestasi standar. Upah insentif ini merupakan alat yang dipergunakan pendukung prinsip adil dalam pemberian kompensasi. Kompensasi (balas jasa) langsung merupakan hak bagi pegawai dan menjadi kewajiban perusahaan untukmembayarnya. Benefit dan Service adalah kompensasi tambahan (finansial atau nonfinansial) yang diberikan berdasarkan kebijaksanaan perusahaan terhadap semua pegawai dalam usaha untuk meningkatkan kesejahteraan mereka. Seperti tunjangan hari raya, uang pensiun, pakaian dinas, kafetaria, mushala, olahraga, dan darmawisata.

Wibowo (2009) menyatakan bahwa kompensasi merupakan kontra prestasi terhadap penggunaan tenaga atau jasa yang telah diberikan oleh tenaga kerja. Kompensasi merupakan jumlah paket yang ditawarkan organisasi kepada pekerja sebagai imbalan atas penggunaan tenaga kerjanya. Dilihat dan cara pemberiannya, kompensasi merupakan kompensasi langsung dan kompensasi tidak langsung. Kompensasi langsung merupakan kompensasi manajemen seperti upah dan gaji atau pay for performance seperti insentif dan Gain sharing. Sementara itu, kompensasi tidak langsung dapat berupa tunjangan atau jaminan keamanan dan kesehatan. Mangkunegara (2014) Pengertian kompensasi menurut Anwar Prabu Mangkunegara adalah sesuatu yang dipertimbangkan sebagai suatu yang sebanding.Dalam kepegawaian, hadiah yang bersifat uang merupakan kompensasi yang diberikan kepada pegawai sebagai penghargaan dari pelayanan mereka. Sunyoto (2013) Pengertian kompensasi menurut Agus Sunyoto adalah konsep yang lebih luas, kompensasi adalah semua bentuk kembalian atau imbalan (return) finansial, jasa-jasa berwujud dan tujuan-tujuan yang diperoleh sebagai dari sebuah hubungan kepegawaian. Panggabean (2013) Pengertian kompensasi menurut Mutiara S. Panggabean adalah setiap bentuk penghargaan yang diberikan karyawan sebagai balas jasa atas kontribusi yang mereka berikan kepada organisasi. Sedarmayanti(2014) Pengertian kompensasi menurut Sedarmayanti adalah segala sesuatu yang diterima oleh karyawan sebagai balas jasa kerja mereka.

\subsection{Kinerja Dosen}

Menurut Gibson (2000) kinerja adalah "the desire of any employees behavior performance." Menurut Smith sebagaimana dalam Sedarmayati (2001) "Performance is 
output drive from processes human or otherwise." Definisi ini membatasi pengertian kerja sebagai hasil atau keluaran dari suatu proses manusia atau lainnya.

Istilah kinerja/prestasi sebenamya adalah pengalih-bahasaan dari kata dalam bahasa Inggris "performance" (Ruky 2001). Dalam kamus The New Webster Dictionary yang dikutip Ruky pada halaman yang sama memberikan tiga arti bagi kata "performance" sebagai berikut:

a. Adalah "prestasi" yang digunakan daIam konteks atau kalimat misalnya tentang "mobil yang sangat cepat" (high performance car).

b. Adalah "pertunjukan" (unjuk) yang biasanya digunakan dalam kalimat "folk dance performance", atau "pertunjukan tari-tarian rakyat".

c. Adalah "pelaksanaan tugas" misalnya dalam kalimat "in performing his her duties".

Bernardin (2003) mendefinisikan "Performance is defined as the record of outcomes produced on a specified job function or activity during a specified time period" (Kinerja atau prestasi adalah catatan tentang hasil-hasil yang diperoleh dari fungsi-fungsi pekerjaan tertentu atau kegiatan tertentu selama kurun waktu tertentu)." Bernardin (2003) membatasi kinerja sebagai rekaman hasil yang diperoleh dari fungsi kerja tertentu atau aktivitas selama periode tertentu. Berdasarkan batasan tersebut kinerja merupakan hasil yang diperoleh atau prestasi kerja dari beberapa aktivitas kerja, baik perorangan maupun kelompok dalam suatu organisasi selama kurun waktu tertentu dicatat dan didokumentasikan. Berardin dan Russell lebih menekankan pada hasil atau apa yang keluar (outcome) dari suatu pekerjaan dan kontribusi mereka dalam organisasi. Kinerja (performance) merupakan kombinasi dari motivasi, kemampuan (ability) dan segala sesuatu yang diperlukan. Dalam persamaan itu, motivasi dan kemampuan merupakan faktor internal dari individu yang bersangkutan, sedangkan segala sesuatu yang lain lebih bersifat eksternal. Ini berarti bahwa kegagalan atau keberhasilan kinerja seseorang dipengaruhi oleh faktor internal dan faktor eksternal.

\subsection{Hipotesis Penelitian}

Hipotesis penelitian ini adalah:

1. Diduga komitmen berpengaruh positif dan signifikan terhadap kinerja dosen PTS

2. Diduga kompensasi berpengaruh positif dan signifikan terhadap kinerja dosen PTS

\section{Metode Penelitian}

Desain penelitian ini adalah deskriptif kuantitatif dengan metode survey dalam pengambilan datanya. Jenis penelitian ini termasuk dalam konfirmatori analisis, yaitu untuk menguji pengaruh komitmen dan kompensasi terhadap kinerja dosen PTS di Kota Palembang. Populasi dalam penelitian ini adalah seluruh dosen tetap pada PTS di Kota Palembang. Sampel penelitian ini adalah 44 orang dosen tetap yang diambil secara klaster random sampling dari beberapa PTS di Kota Palembang. Klasterisasi dilakukan berdasarkan bentuk perguruan tinggi, yaitu Universitas (24 dosen), Sekolah Tinggi (10 dosen), Akademi (5 dosen) dan Politeknik (5 dosen). Instrumen penelitian digunakan kuesioner yang terdiri dari beberapa butir pernyataan (indikator), dimana variabel komitmen terdiri dari 15 indikator, variabel kompensasi ada 14 indikator dan variabel kinerja ada 15 indikator. Sebelum dilakukan penelitian, instrumen tersebut telah 
dilakukan uji coba dan diuji validitas dan reliabilitasnya. Hasil ujicoba instrumen menunjukkan bahwa semua indikator valid dan reliabel sehingga layak untuk dijadikan instrumen penelitian ini. Teknik analisis data dilakukan dengan analisis regresi berganda dengan bantuan paket program SPSS.

\section{Pembahasan}

\subsection{Analisis Deskriptif}

Deskripsi masing-masing variabel dijelaskan pada masing-masing indikator yang telah dilakukan penilaian berupa pernyataan sekala sikap oleh responden dari sangat tidak setuju (skor 1) sampai sangat setuju (skor 5). Analisis deskriptif dilakukan untuk mengungkapkan penilaian atau klasifikasi pada masing-masing indikator yang ada pada variabel tersebut. Variabel komitmen dengan 15 item pernyataan yang diperoleh dari 44 orang responden diperoleh rata-rata tingkat penilaian sebesar 75,48 persen dari skor maksimum. Hal ini berarti bahwa persepsi responden terhadap komitmen dalam distribusi sudah relatif cukup baik. Intensitas jawaban responden pada variabel kompensasi sebesar 74,68 persen dari skor maksimum. Hal ini berarti bahwa persepsi responden terhadap kompensasi dalam distribusi sudah relatif baik. Skor persepsi responden terhadap kinerja dosen diperoleh sebesar 78,58 persen dari skor maksimum variabel. Hal ini berarti bahwa tingkat kinerja dosen relatif cukup baik, karena tingkat pencapaiannya lebih dari 70 persen. Persepsi ini menunjukkan bahwa masing-masing variabel telah dapat mengukur sesuai dengan yang akan diukur.

\subsection{Hasil Pengujian Hipotesis}

Hasil analisis regresi dengan bantuan program SPSS for Windows diperoleh rangkuman model seperti pada Tabel 1 .

Tabel 1. Rangkuman Model Regresi

\begin{tabular}{|l|r|r|r|r|}
\hline Model & \multicolumn{1}{|c|}{$\mathrm{R}$} & R Square & \multicolumn{1}{c|}{$\begin{array}{c}\text { Adjusted R } \\
\text { Square }\end{array}$} & $\begin{array}{c}\text { Std. Error of } \\
\text { the Estimate }\end{array}$ \\
\hline 1 & $.795^{\mathrm{a}}$ & .633 & .615 & .19040 \\
\hline
\end{tabular}

a. Predictors: (Constant), Kompensasi, Komitmen

Berdasarkan tabel di atas, diperoleh nilai korelasi ganda sebesar 0,795. Nilai tersebut menunjukkan adanya hubungan positif yang moderat antara Komitmen dan Kompensasi dengan Kinerja Dosen pada PTS di Kota Palembang. Nilai koefesien determinasi $\left(\mathrm{R}^{2}\right)$ sebesar 0,615 menunjukkan bahwa model tersebut dapat menjelaskan variasi data yang ada sebesar 61,5 persen.

Pengujian secara simultan dilakukan dengan analisis varians (ANOVA- Analysis of Variance) menggunakan statistik uji-F. Hasil perhitungan analisis varians dan hasil pengujian hipotesis diperoleh seperti pada Tabel 2.

Tabel 2. ANOVA untuk Model Komitmen dan komepensasi dengan Kinerja Dosen

\begin{tabular}{|l|c|c|c|c|c|}
\hline Model & $\begin{array}{c}\text { Sum of } \\
\text { Squares }\end{array}$ & df & $\begin{array}{c}\text { Mean } \\
\text { Square }\end{array}$ & F & Sig. \\
\hline
\end{tabular}




\begin{tabular}{|ll|r|r|r|r|r|}
\hline 1 & Regression & 2.558 & 2 & 1.279 & 35.285 & $.000^{\mathrm{b}}$ \\
& Residual & 1.486 & 41 & .036 & & \\
Total & 4.045 & 43 & & & \\
\hline
\end{tabular}

a. Dependent Variable: Kinerja Dosen

b. Predictors: (Constant), Kompensasi, Komitmen

Tabel 2 diperoleh nilai F-hitung sebesar 35,285 atau nilai p-value (Sig.) sebesar 0,000, karena nilai $p$-value $<\alpha$, maka $\mathrm{H}_{0}$ ditolak. Artinya, pada taraf nyata sebesar $5 \%$ dapat dinyatakan bahwa ada pengaruh yang positif dan signifikan antara Komitmen dan kompensasi terhadap Kinerja Dosen pada PTS di Kota Palembang.

Nilai-nilai koefesien regresi hasil pendugaan dengan metode kuadrat terkecil (Ordinary Least Square) dari pengaruh masing-masing faktor atau variabel terhadap Kinerja Dosen PTS di Kota Palembang terlihat seperti pada Tabel 3.

Tabel 3. Nilai Koefesien Regresi

\begin{tabular}{|c|c|c|c|c|c|c|}
\hline \multirow{2}{*}{\multicolumn{2}{|c|}{ Model }} & \multicolumn{2}{|c|}{$\begin{array}{c}\text { Unstandardized } \\
\text { Coefficients }\end{array}$} & \multirow{2}{*}{$\begin{array}{c}\text { Standardized } \\
\text { Coefficients } \\
\text { Beta } \\
\end{array}$} & \multirow[b]{2}{*}{$\mathrm{t}$} & \multirow[b]{2}{*}{ Sig. } \\
\hline & & $\mathrm{B}$ & Std. Error & & & \\
\hline \multirow[t]{3}{*}{1} & (Constant) & 1.057 & .344 & & 3.078 & .004 \\
\hline & Komitmen & .261 & .065 & .392 & 4.044 & .000 \\
\hline & Kompensasi & .505 & .079 & .615 & 6.354 & .000 \\
\hline
\end{tabular}

a. Dependent Variable: Kinerja Dosen

Berdasarkan Tabel 3. dapat diambil kesimpulan sebagai berikut.

1. Nilai koefesien regresi untuk faktor Komitmen diperoleh sebesar 0,261 dengan nilai thitung sebesar 4,044 dan p-value sebesar 0,000. Karena $p$-value $<5 \%$, maka $\mathrm{H}_{0}$ ditolak. Artinya dengan kepercayaan sebesar 95\% dapat dinyatakan bahwa faktor Komitmen berpengaruh signifikan terhadap Kinerja Dosen pada PTS di Kota Palembang.

2. Nilai koefesien regresi untuk faktor Kompensasi diperoleh sebesar 0,505 dengan nilai t-hitung sebesar 6,354 dan p-value sebesar 0,000. Karena $p$-value $<5 \%$, maka $\mathrm{H}_{0}$ ditolak. Artinya dengan kepercayaan sebesar $95 \%$ dapat dinyatakan bahwa faktor Kompensasi berpengaruh signifikan terhadap Kinerja Dosen pada PTS di Kota Palembang.

Secara parsial terlihat bahwa dari kedua variabel bebas semuanya berpengaruh signifikan terhadap Kinerja Dosen pada PTS di Kota Palembang. Faktor yang berpengaruh dominan terhadap Kinerja Dosen pada PTS di Kota Palembang adalah faktor kompensasi, artinya kompensasi yang semakin tinggi akan meningkatkan Kinerja Dosen pada PTS di Kota Palembang.

Hasil ini menegaskan bahwa kebutuhan dosen pada PTS masih belum tercukupi, sehingga kompensasi menjadi faktor dominan, karena dengan adanya kompensasi dapat 
meringankan beban seorang dosen dalam memenuhi kebutuhan hidupnya. Kompensasi sendiri tidak hanya berupa finansial saja, namun dapat berupa non finansial seperti tunjangan kesehatan, tunjangan keluarga dan lain sebagainya (Gunarto, dkk, 2020). Jaminan kesehatan dan hari tua dapat meringankan beban keluarga dosen (Idris, dkk, 2017).

Faktor kedua yang dapat mendorong kinerja dosen adalah komitmen organisasi maupn pimpinan dalam hal ini lebih pada yayasan PTS. Hasil ini sejalan dengan apa yang diungkapkan oleh Farid (2015) menyatakan bahwa kehidupan kerja sangat dipengaruhi oleh komitmen organisasi. Melalui komitmen yang kuat berbagai kenyamanan dalam bekerja akan diperoleh sehingga kinerja seorang dosen juga semakin baik.

\section{Simpulan}

Terdapat pengaruh yang positif dan signifikan antara komitmen organisasi dan kompensasi terhadap Kinerja Dosen pada PTS di Kota Palembang. Hal ini menunjukkan bahwa semakin kuat komitmen dalam organisasi dan semakin tinggi komitmen berpengaruh pada meningkatnya Kinerja Dosen pada PTS di Kota Palembang. Untuk itu dibutuhkan komitmen yang kuat khususnya dari pemilik (yayasan) dan pengelola (pimpinan PTS) dengan dosen tetapnya, disamping itu kompensasi yang memadai sesuai kebutuhan layak seorang dosen juga menjadi perlu untuk diperhatikan.

\section{Daftar Pustaka}

Allen and Meyer. (2014). The Measurement and Antecedents of Affective, Contintinuance and Normative Commitment to Organitazion. Penerbit: PT Elex Media Komputindo, Jakarta

Bernardin, H. John and Joice E. A. Russell, (2003) Human Resource Management, International Edition, McGraw-Hill Book Co.

Farid, Hadi, Zahra Izadi, Ismi Arif Ismail \& Farhad Alipour (2015) Relationship between quality of work life and organizational commitment among lecturers in a Malaysian public research university, The Social Science Journal, 52: 1, 54-61, DOI: 10.1016 / j.soscij.2014.09.003

Gibson, James L, Ivancecich, John M, Donnely James H, (2000), Organization Behavior, Structure, Process, Texas, Business Publications Inc.

Greenberg dan Baron, (2013).Budaya dan Komitmen Organisasi. Terjemahan. Jakarta: Erlangga.

Gunarto, M., Yunilda, \& Yessy Widiastuty. (2020). The Effect Of Compensation And Commitment To Employee Motivation In A Sub-District Palembang. Dinasti International Journal of Management Science, 1(5), 635-645. https://doi.org/10.31933/dijms.v1i5.276

Idris, Muhammad Hamzah, Hamzah, Djabir, Sudirman, Indrianty, and Hamid, Nurdjanah (2017). The Relevance of Financial and Non-Financial Compensation on Professionalism and Lecturers Performance: Evidence from Makassar Private Universities (Indonesia). Journal of Asian Development Vol 3 (2). DOI. 10.5296/jad.v3i2.11491

Hasibuan, Malayu. (2014). Manajemen Sumber Daya Manusia. Jakarta: Bumi Aksara Luthans, Fred. (2011). Perilaku organisasi. Yogayakarta : Andi 
Panggabean, Mutiara Sibarani.(2012).ManajemenSumber Daya Manusia.Jakarta: GhaliaIndonesia.

Mangkunegara, Anwar Prabu AA. (2014) Manajemen Sumber Daya Manusia Perusahaan, Bandung : Penerbit: PT. Remaja Rosdakarya

Ruky, Achmad, (2001) Sistem Manajemen Kinerja : Panduan Praktis untuk Merancang dan Meraih Kinerja Prima, Jakarta, Gramedia Pustaka Utama,

Sudarmanto, (2009), Kinerja dan Pengembangan Kompetensi SDM, Yogyakarta, Pustaka Pelajar

Sedarmayanti, (2001) Sumber Daya Manusia dan Produktivitas Kerja, Bandung, Mandar Maju,

\section{Copyright Disclaimer}

Copyright for this article is retained by the author(s), with first publication rights granted to the journal. 